\title{
Knowledge, Attitude and Practice of Temporary Artificial Methods of Contraception Among Women of Child Bearing Age in Awka South Local Government Area
}

\author{
I. G. Eyisi ${ }^{1}$, C. C. Nwachukwu ${ }^{1}$, I. A. Njelita ${ }^{1}$, U. M. Umeh ${ }^{1}$, C. S. Eyisi ${ }^{2} \&$ L. N. Igbokwe \\ ${ }^{1}$ Department of Community Medicine, Faculty of Clinical Medicine, Chukwuemeka Odimegwu Ojukwu \\ University, Nigeria \\ ${ }^{2}$ Department of Medicine, College of Medicine, University of Nigeria Teaching Hospital, Nigeria \\ ${ }^{3}$ Udi General Hospital, Udi, Enugu State, Nigeria \\ Correspondence: Dr. Eyisi I. G., Department of Community Medicine, Faculty of Clinical Medicine, \\ Chukwuemeka Odimegwu Ojukwu University, Nigeria.
}

Received: March 6, 2019 Accepted: June 27, 2019 Online Published: July 29, 2019

doi:10.5539/gjhs.v11n9p153 URL: https://doi.org/10.5539/gjhs.v11n9p153

\begin{abstract}
Background: Contraception is the procedure of preventing pregnancy when it is not desired (MedicineNet, 2018). It is broadly divided into natural and artificial methods of which the artificial is further subdivided into Temporary and Permanent methods.

Methods: This research exercise was conducted in Awka South Local Government Area in Anambra State, Nigeria consisting of Nine Towns namely Amawbia, Awka, Ezinato, Isiagu, Mbaukwu, Nibo, Nise, Okpuno and Umuawulu (Wikipedia, 2018). Questionnaires were administered by an interviewer which consists of 5 sections while data was analyzed using SPSS (Statistical Package for Social Sciences) and the results were chi-squared at appropriate times and data were presented in forms like prose, tables, and charts.
\end{abstract}

Results: $78.9 \%$ of the respondents were aware of temporary artificial methods of contraception; $44.3 \%$ of correspondents with knowledge of temporary artificial contraceptives got their information from friends while $22.4 \%$ of the correspondents got theirs from school which reflects a low level of sex education in our homes and religious institutions. Only $18.4 \%$ could actually identify intra-uterine contraceptive devices from a list of options While $43.2 \%$ could actually identify a contraceptive pill within a list of options. The study also showed that the oral contraceptive pill most known to $50.4 \%$ of the correspondents is postinor- 2 while the intra-uterine device most commonly known to those with knowledge of intra-uterine contraceptive device was Mirena which is about $65.8 \%$ of the correspondents. Also, this research revealed that $49.2 \%$ admitted to having used temporary artificial contraceptives.

Conclusion: Despite the high level of awareness of temporary artificial contraceptives methods, its level of practice is quite low in this part of the country and the major factors influencing the knowledge and attitude of the participants towards temporary artificial contraceptives are marital status and educational level.

Keywords: temporary artificial methods contraception, child bearing age, artificial contraceptives

\section{Introduction}

Contraception is the procedure of preventing pregnancy when it is not desired (Medicine Net, 2018). It is broadly divided into natural and artificial methods. The artificial is further subdivided into Temporary and Permanent methods. The earliest documented acts of artificial contraception can be found in the Egyptian Eber papyrus (dating back to $1550 \mathrm{BC}$ ) which gave accounts of using substances like honey, acacia, and lint to prevent pregnancy (Amy \& Cuomo, 2010; Beker et al., 2005). Also in ancient Greece, silphium was used extensively and this led to the extinction of the plant (Times, 2016). In Asia, they used substances like ghee, rock salt, red chalk, powdered palm leaf (Times, 2016).

Following the theory of population propounded by Thomas Malthus, his ideas came to carry great weight in British Political Debates and they started making movements and promoting birth strategies i.e. the Malthusians (Fryer, 2018). These led to advancements in contraception device formulations such that by the early $18^{\text {th }}$ Century, the 
barrier method (diaphragms' \& condoms) came into use (Fryer, 2018; Dingwall, 1953) made from the animal gut or vulcanized rubber.

In 1909, Richard Richter developed the first intra-uterine device which was made from silkworm gut by 1880-1900, birth rates started dropping drastically in developed countries, for example, the United Kingdom, a drop from about 35 per 1000 to 29 per 1000 was recorded (Fritz \& Speroff, 2011; Draznin, 2001). Family Planning Clinics were opened (the first documented was established by Marie Stopes in Britain 1921). In 1951, Carl Djerassi, a Mexican Chemist synthesized the hormones in progesterone pills but was not allowed to distribute it. Then, in the late $1950^{\mathrm{s}}$, Gregory Pincus and John Rock developed the first birth control pills (Mestranol) and it became available for public use in 1960 (American Experience, 2016).

Since then, many other contraceptive methods started becoming popular. They include other barrier methods such as cervical caps (a tight rubber sheath is worn over the external of the cervix to prevent the passage of sperms through it), diaphragms (a small dome-shaped rubber flip inserted into the vagina to cover the mouth of the cervix) and other female condoms. The hormonal contraceptives also becoming popularized and they include progesterone only pills e.g. high-dose levonorgestrel (Plan B). Combined oral contraceptives e.g. combination of ethynylestradiol and progestin or combination of Mestranol and nor-ethyesterone. These are progestogens and estrogens combined in a definite ratio. The progesterone only pills can also be used as Emergency Contraception (EC, as "morning after pills").

Some of these hormones have also been made available in a formulation like vaginal rings, transdermal patches, progesterone, intra-uterine devices e.t.c. We also have the non-hormonal intra-uterine devices of which the most common are the copper intra-uterine devices. The American Congress of Gynecologists \& obstetricians recommended contraceptive pills as over the counter drugs in 2014, and September 26 has been chosen to be World Contraception Day (Akin, 2016).

\subsection{Statement of Problem}

Abortions (especially induced unsafe abortions) contribute significantly to maternal morbidity and mortality. 26 to 53 million induced abortions occur worldwide annually, of this, about 20 million are unsafe abortions, resulting to about 70,000 maternal deaths worldwide annually, with 69,000 of them happening in developing countries, exemplified by Nigeria (Emechebe et al., 2016). It is a well-known fact that the majority of induced abortions is attributable to unwanted pregnancy resulting from unprotected sexual intercourse between two mutually consenting individuals (Emechebe et al., 2016). Between the year 2010 to 2014, the average number of abortions worldwide as estimated by world health organization was approaching 57 Million each year (WHO, 2018). In Nigeria, it was estimated that as much 1.4million abortions are performed yearly, resulting in some 35,000 deaths yearly (PRB, 2018). Apart from the mortalities accrued to unsafe abortions, many long term morbidities of which the most economically important is sub-fertility can also be attributed to unsafe abortions. Other serious sequelae of unwanted pregnancies are overpopulation, which has been wreaking untold havoc in the planning and economic state of the country (USAID, 2012). The population of Nigeria grew from 185,989,640 in 2016 to 190,886,311 in 2017 , then to $195,875,2372018$ (an average growth rate of $2.7 \%$ per annum).

In the light of all these, comes the issue of knowledge, attitude and practice of different methods of contraception Although awareness of contraception is quite high according to data from various entities, the attitude and practice is not quite as adequate, relative to the world's need for population control, mortality \& morbidity reduction, especially in the developing countries. About 222 Million women who want to prevent pregnancy in developing countries are not using modern birth control methods (USAID, 2012). Among the leading causes of this poor attitude and limitations to using include cultural or religious beliefs, disagreements between couples, fear of side effects amongst other things.

In the face of increasing maternal mortality rate, where unsafe abortion is a major contributing factor, and also faced with an Explosively growing population in Nigeria with its detrimental sequelae, it is imperative that proper awareness, education, and campaigns for correct use and attitude towards different methods of contraception be carried out (Emechebe et al., 2016; WPR, 2018).

This will go a long way to aid the government in planning and managing the country effectively, better the standards of living of the citizens reduce avoidable maternal deaths. It will also reduce the morbidities suffered by women as a result of induced abortions, family and reproductive health will be enhanced in many families, with each family having a responsible family size, members of which can be adequately brought up for good contributions towards the betterment of the society. 


\subsection{Objectives of the Study}

The general objective of this study is to acquire knowledge on the attitude and practice of temporary artificial methods of contraception in women of Child Bearing Age in Awka South local government area.

Specific Objectives

1) To determine the knowledge of temporary artificial methods of contraception in women of child bearing age in Awka South local government area.

2) To determine attitude towards temporary artificial methods of contraception in women of child bearing age in Awka South local government area

3) To determine the practice of temporary artificial methods of contraception in women of child bearing age in Awka South local government area

\subsection{Research Questions}

1) Do most women in Awka South local government area have knowledge of temporary artificial methods of contraception?

2) Is there a difference in the level of knowledge of temporary artificial methods of contraception between married and unmarried women in Awka South local government area?

3) Is there a difference in the attitude towards temporary artificial methods of contraception between married and unmarried women in Awka South local government area?

4) Is there a difference in the level of practice of temporary artificial methods of contraception between married and unmarried women in Awka South local government area?

5) Is there a difference in the level of knowledge of temporary artificial methods of contraception in women of childbearing age in Awka South local government area with respect to the level of Education?

6) Is there a difference in the level of practice of temporary artificial methods of contraception in women of childbearing age in Awka South local government area with respect to the level of Education?

7) Is there a difference in the level of practice of temporary artificial methods of contraception in women of childbearing age in Awka South local government area with respect to religion?

\subsection{Null Hypotheses}

i. There is no difference in the level of knowledge of temporary artificial methods of contraception between married and unmarried women in Awka South local government area.

ii. There is no difference in the level of practice of temporary artificial methods of contraception between married and unmarried women in Awka South local government area

\subsection{Alternate Hypotheses}

i. There is a difference in the level of knowledge of temporary artificial contraception between married and unmarried women of childbearing age in Awka South local government area.

ii. There is a difference in the level of practice of temporary artificial contraception between married and unmarried women of childbearing age in Awka South local government area.

\subsection{Scope of the Study}

The scope of this study covers the knowledge, attitude, and practice of temporary artificial methods of contraception in women of childbearing age in Awka South local government area

\section{Literature Review}

\subsection{Knowledge of Methods of Temporary Artificial Contraception}

In a study on knowledge of contraception in an urban population of north India carried out interviews with attendees of gynecology and obstetrics outpatient clinics, and indoor patients of three hospitals of the urban population. Results revealed that a total of $55.2 \%$ subjects were aware of contraceptive methods, mostly barriers (52.7\%), IUCD (46.1\%) and oral pills (43.2\%) (Inflibnex, 2018). Another study in Argentina were $71.5 \%$ out of the 672 respondents were females, showed that most students had knowledge about the male condom, contraceptive pill, and intrauterine contraceptive devices as methods of contraception (Nakim et al., 2013). In a study to assess the knowledge about contraceptive practices in India, $99 \%$ of women were aware of some methods of contraception. 
In a study on knowledge about family planning among female students in Addis Ababa, 86\% (134/156) of them had heard about contraceptives. Most of them knew about condoms (85\%) and contraceptive pills (40\%) but knowledge about permanent methods and Copper-T was poor (average 12\%). Most students thought contraceptives were to be used to prevent unwanted pregnancy (35\%) and for birth spacing (30\%) (Inflibnex, 2018). In a cross-sectional survey in Kinshasa, the Democratic Republic of Congo, condom was the most widely known modern contraceptive method since it was cited by $43 \%$ of women; the Pill was by only $28 \%$, Injectable $16.2 \%$, IUD $8 \%$, spermicidal foam $2 \%$, and the diaphragm by less than $2 \%$. Teenagers and young adults (15-24 years) were less knowledgeable of modern methods (Kazembe et al., 2003). A study on knowledge of contraceptives in Ghana, $96 \%$ percent of the respondents had heard about contraceptive services whilst $4 \%$ indicated that they had never heard about the services. Pills, Injectable, Condoms and IUCD forming $67.1 \%$, $57.3 \%, 50.9 \%$, and $45.9 \%$ respectively were the modern FP methods identified by the respondents. The others identified were Norplant, 36.4\%, Diaphragm, 20.4\%, Foam, 16.5\%, and Sterilization (Knust-edu, 2003; RAND, 1997).

In a study carried out to determine the knowledge of family planning (FP) among women of childbearing age in a community in south-south Nigeria [Abak, Akwa IbomState] Nigeria among women of childbearing age (15-45 years] A total of 338 questionnaires were retrieved. About $45.9 \%$ of the respondents were aged $15-25$ years, 136 (40.2\%) were married, and1(5.0\%had no form of formal education.299 (88.5\%) had heard of FP and the commonest source of information was a clinic, $112(37.5 \%)$. The most commonly mentioned FP were injectable, $134(44.8 \%)$ and pills, 81 (27.1\%) respectively (Ekong, 2016). In a study on knowledge of artificial contraceptive methods, 334 Nigerian, non-pregnant women, living in a high density, low-income urban area of Enugu were interviewed, About 97.6\% had knowledge of it (Inflibnex, 2018).

\subsection{The attitude of Respondents Towards Temporary Artificial Contraceptive Methods}

Studies on attitude towards artificial contraceptive methods among women presenting for voluntary termination of pregnancy (MTP) or septic and incomplete abortions in India, only20.3\% were willing to accept IUD (Inflibnex, 2018). In a study on attitude towards artificial contraceptive methods, clients at ten family planning clinics in Nairobi ( $\mathrm{n}=282)$ and conducted four focus group discussions with students at two Universities in Kenya $(\mathrm{n}=42)$, Results showed that despite relatively low levels of awareness and widespread misinformation, when the method was explained, both clients and students expressed considerable interest, but also expressed some health and other concerns (Inflibnex, 2018).

In another study on attitude towards temporary artificial contraceptives among female students in Dilla secondary school, Ethiopia ( $\mathrm{n}=263), 191 \quad(76.7 \%)$ said that contraceptives are used to prevent unwanted pregnancy, 209 $(83.9 \%)$ to limit or space childbirth, and $48(19.3 \%)$ answered to prevent sexually transmitted diseases (Table 4$)$. Attitude towards contraception One hundred seventy-eight (71.5\%) students had a favorable attitude towards contraceptives. Among them, $111(63.4 \%)$ are orthodox Christians having a positive attitude, $56(31.5 \%)$ protestant, $6(3.4 \%)$ Catholic and $5(2.8 \%)$ of Muslim students have a positive attitude towards contraceptive (Benta et al., 2017). In a study carried out to determine the attitude towards family planning (FP) among women of childbearing age in a community in south-south Nigeria [Abak, Akwa Ibom State] Nigeria among women of childbearing age (15-45 years] A total of 338 questionnaires were retrieved. About $45.9 \%$ of the respondents were aged 15-25 years, 136 (40.2\%) were married and $17(5.0 \%)$ had no form of formal education. Many, up to 114 (33.8\%) had a negative attitude (Ekong, 2016).

334 Nigerian, non-pregnant women, living in a high density, low-income urban area of Enugu were interviewed on attitude towards artificial contraception, approval was high, 86.2\% (Inflibnex, 2018). In the study among tertiary institutions in Anambra State, 245 (53.8\%) of the respondents believe that emergency contraceptive drugs should not be sold by the patent medicine dealers, $150(33.0 \%)$ approved of it to be sold in the chemist stores while 60 $(13.2 \%)$ were indifferent. While $222(50.3 \%)$ of the respondents felt that doctors' prescription is necessary before the dispensation of emergency contraceptive drugs, 98 (21.3\%) felt otherwise and 128 (28.3\%) were indifferent.

\subsection{The practice of Different Temporary Artificial Methods of Contraception}

In one study to asses the use of temporary artificial contraceptives, Condom use only was most frequent and ranged from $52.7 \%$ in Sweden to $89.2 \%$ in Greece. Dual use of condoms and contraceptive pills was also relatively frequent, ranging from $2.6 \%$ in Croatia to $28.8 \%$ in Canada. The use of contraceptive pills was most frequent in northern and Western Europe No contraceptive at last intercourse was reported by $13.2 \%$ of students (Inflibnex, 2018). In a study on practices of contraception in an urban population of north India carried out interviews with attendees of gynecology and obstetrics outpatient clinics, and indoor patients of three hospitals of the urban population only $31.7 \%$ had ever used barrier contraception, IUCD 10.3\% and oral pills 3.3\% (Inflibnex, 2018). In 
a study for Practice of Contraceptive Use Among Female Students of Dilla Secondary and Preparatory School, Dilla Town, South Ethiopia, 2014 A total of 263 female students participated in the study with a response rate of $91.3 \%$. A total of $39(15.7 \%)$ respondents had ever used contraceptive method. Of 39 students who practiced contraceptive $26(66.7 \%)$ were unmarried and $13(33.3 \%)$ were married. Among those that practiced contraceptives 19 (48.7\%) were orthodox, 15 (38.5\%) were protestant, 3 (7.7\%) were Muslim, and $2(5.1 \%)$ were Catholic students. The commonly used contraceptive method was pills (Benta et al., 2017).

Research on artificial contraceptive use among in-school adolescents in Nigeria. Among 2,460 secondary school children surveyed in two southeastern Nigerian states, only $17 \%$ of sexually active students had ever used a contraceptive method other than abstinence (Inflibnex, 2018). 334 Nigerian, non-pregnant women, living in a high density, low-income urban area of Enugu were interviewed on the practice of family planning. the practice of family planning was low, as only $20 \%$ of the women were on a family planning method. The commonest methods for both ever use and current use were safe period/Billings, condom, IUCD and injections (Inflibnex, 2018).

\section{Methodology}

\subsection{Area of Study}

Awka South is an Urban-Local Government Area in Anambra State, Nigeria. It lies between the latitude of $6^{0} 10 \mathrm{~N} /$ $7^{0} 04 \mathrm{E}$ and longitude of $6.167^{\circ} \mathrm{N} / 7.067^{\circ} \mathrm{E}$ (Akin, 2006). It consists of Nine Towns namely Amawbia, Awka, Ezinato, Isiagu, Mbaukwu, Nibo, Nise, Okpuno, and Umuawulu (Wikipedia, 2018).

The Local Government has a landmass of about $170 \mathrm{~km}^{2}$ and a population of 189,049 , based on the 2006 National Census Report, ${ }^{11}$ with a population density of $1,112 / \mathrm{km}^{2}$ (Wikipedia, 2018).

The number of males was given to be 96,900 while that of females was about 92,700 and number of females of childbearing age (that is, 15 to $45 \mathrm{yrs}$ ) to be about 64,500 (NBS, 2006).

Awka people are popular for their mastery in the art of blacksmithing. In the present day Awka, they are known more for their academic and business exploits.

The majority of the population are Igbos and Christians by Religion (Blogger 2013).

\subsection{Study Population}

This consists of women of childbearing age in the Study Area

\subsection{Inclusion Criteria}

Women of childbearing age, in good enough condition, to give consent and reliable answers.

\subsection{Exclusion Criteria}

Women of childbearing age that are not within the age bracket of 18 to 45 years

\subsection{Study Design}

A Cross-sectional study.

Sample Size Determination:

Using the formula for calculating the minimum sample size for cross-sectional study on total sample size greater 10,000

$$
\mathrm{N}=\frac{Z^{2} P q}{D^{2}}
$$

Where $\mathrm{n}=$ minimum sample size

$\mathrm{Z}=$ standard normal deviation $=1.96$

$\mathrm{P}=$ prevalence from previous study in Nnamdi Azikiwe University Teaching Hospital, Nnewi to asses South-East Women on knowledge of artificial contraceptives $=80 \%(0.8)^{12}$

$\mathrm{D}=$ Margin of error tolerated $=5 \%(0.05)$

$\mathrm{Q}=1-\mathrm{P}=1-0.8 \%=0.2$

Hence

$$
\mathrm{n}=\frac{(1.96)^{2} \times 0.8 \times 0.2}{(0.05)^{2}}
$$




$$
\begin{gathered}
=\frac{3.84 \times 0.8 \times 0.2}{0.0025} \\
=245.76
\end{gathered}
$$

Hence $n \approx 246$, but the non response will be given by

$10 / 100^{\mathrm{x} 246}=24.6$

Hence calculated sample size $=246+24.6 \approx 270$

\subsection{Sampling Method}

Multi-stage sampling technique was used. For the Multi-Stage Sampling

Stage I- Out of the 9 towns in Awka south local government, 2 towns were chosen by simple random sampling (by paper balloting)

Stage II- In each town, 1 village was chosen by simple random sampling (paper balloting)

Stage III- one street was chosen in each village by Simple random sampling( paper balloting)

Stage IV- systematic random sampling was used to chose every $3^{\text {rd }}$ house in the street, whereby cooperative subjects that met the inclusion criteria were interviewed.

\subsection{Instruments for Data Collection}

An interviewer-administered questionnaire was used and it consists of 5 sections which are:

Section A: Socio-demographic details

Section B: Knowledge of temporary artificial contraception methods among women of childbearing age in Awka South local government area

Section C: Attitude towards temporary artificial contraceptive among women of child bearing age in Awka South local government area

Section D: Practice of temporary artificial contraception among women of child bearing age in Awka South local government area

3.8 Data Analysis

Data were analyzed using SPSS (Statistical Package for Social Sciences). The results were chi-squared at appropriate times and data were presented in forms like prose, tables, and charts.

\subsection{Ethical Considerations}

Ethical clearance was obtained from COOUTH Ethical committee and Participation of respondents was purely voluntary.

Informed verbal consent was obtained from all that participated in the study and data was handled in a confidential manner. 


\section{Quantitative Findings}

Table 1. Socio-demographic variables

\begin{tabular}{|c|c|c|c|}
\hline Variables & & Frequency & Percentage (\%) \\
\hline \multirow[t]{6}{*}{ Age } & $16-20$ & 34 & $13.0 \%$ \\
\hline & $21-25$ & 63 & $24.1 \%$ \\
\hline & $26-30$ & 61 & $23.4 \%$ \\
\hline & $31-35$ & 49 & $18.8 \%$ \\
\hline & $36-40$ & 27 & $10.3 \%$ \\
\hline & $41-45$ & 27 & $10.3 \%$ \\
\hline \multirow[t]{4}{*}{ Marital status } & Single & 118 & $45.4 \%$ \\
\hline & Married & 134 & $51.5 \%$ \\
\hline & Divorced & 2 & $0.8 \%$ \\
\hline & Widowed & 6 & $2.3 \%$ \\
\hline \multirow[t]{5}{*}{ Occupation } & Unemployed & 63 & $25.4 \%$ \\
\hline & Civil servant & 36 & $14.5 \%$ \\
\hline & Trader & 48 & $19.4 \%$ \\
\hline & Housewife & 6 & $2.4 \%$ \\
\hline & Self-employed & 95 & $38.3 \%$ \\
\hline \multirow[t]{4}{*}{ Highest academic level } & No formal & 7 & $2.8 \%$ \\
\hline & Primary school & 23 & $9.2 \%$ \\
\hline & Secondary school & 92 & $36.8 \%$ \\
\hline & Tertiary education & 128 & $51.2 \%$ \\
\hline \multirow[t]{6}{*}{ No of Children } & 1 & 26 & $10.2 \%$ \\
\hline & 2 & 27 & $10.6 \%$ \\
\hline & 3 & 31 & $12.2 \%$ \\
\hline & 4 & 25 & $9.8 \%$ \\
\hline & 5 and above & 30 & $11.8 \%$ \\
\hline & None & 116 & $45.5 \%$ \\
\hline \multirow[t]{5}{*}{ Religion } & Catholics & 136 & $52.1 \%$ \\
\hline & Anglican & 21 & $8.0 \%$ \\
\hline & Pentecostal & 100 & $38.3 \%$ \\
\hline & Muslim & 4 & $1.5 \%$ \\
\hline & African traditional religion & 0 & $0.0 \%$ \\
\hline
\end{tabular}

This table shows $24.1 \%$ were between the age range of $21-25$ years, $23.4 \%$ were between $26-30$ years of age. About half of the participants (51.5\%) were married, 38.3\% self-employed while $25.4 \%$ were unemployed. $51.2 \%$ had tertiary education as their highest level of education, $2.8 \%$ had no formal education, $52.1 \%$ were Christians of the Roman Catholic denomination and 1.5\% were Muslims. Other components of the socio-demographic variables are summarized in the table. 
Table 2. Knowledge of temporary artificial contraception

\begin{tabular}{|c|c|c|c|}
\hline Knowledge Of Temporary Artificial Contraception & & Frequency & Percentage $(\%)$ \\
\hline \multirow{2}{*}{ Do you know any temporary artificial contraceptives? } & Yes & 206 & $78.9 \%$ \\
\hline & No & 55 & $21.1 \%$ \\
\hline \multirow{6}{*}{ Who informed you? } & Family & 6 & $3.0 \%$ \\
\hline & Friends & 89 & $44.3 \%$ \\
\hline & Media & 17 & $8.5 \%$ \\
\hline & Church & 14 & $7.0 \%$ \\
\hline & School & 45 & $22.4 \%$ \\
\hline & Others(hospital) & 30 & $14.9 \%$ \\
\hline \multirow{2}{*}{ Do you know any oral contraceptive pill? } & Yes & 162 & $62.8 \%$ \\
\hline & No & 96 & $37.2 \%$ \\
\hline \multirow{5}{*}{ Examples of oral contraceptive pills include: } & Levora & 30 & $24.8 \%$ \\
\hline & Esto-step & 7 & $5.8 \%$ \\
\hline & Mirena & 10 & $8.3 \%$ \\
\hline & Condoms & 13 & $10.7 \%$ \\
\hline & Postinor & 61 & $50.4 \%$ \\
\hline \multirow{2}{*}{ Do you know any example of Intra-uterine contraceptive device? } & Yes & 134 & $52.3 \%$ \\
\hline & No & 122 & $47.7 \%$ \\
\hline \multirow{4}{*}{ Example of intra uterine contraceptive devices include: } & Mirena & 25 & $29.4 \%$ \\
\hline & Diaphragms & 27 & $31.8 \%$ \\
\hline & Depo-provera & 20 & $23.5 \%$ \\
\hline & Gynefix & 13 & $15.3 \%$ \\
\hline
\end{tabular}

From this table, $78.9 \%$ knew about temporary artificial contraceptives, of which $44.3 \%$ of them got the knowledge from their friends. A half $(50.4 \%)$ of the participants who knew about pills were aware of postinor-2, while the least known method of temporary artificial contraception was intra-uterine devices. Only $18.4 \%$ of those with knowledge of intra-uterine contraceptive devices could correctly identify it from a list of options. Other information is well represented in the table.

Table 3. Cross tabulation comparing the knowledge of temporary artificial contraceptives and marital status

\begin{tabular}{|c|c|c|c|c|c|}
\hline \multirow{2}{*}{ Marital Status } & \multicolumn{2}{|c|}{ Do you know any temporary artificial contraceptives? } & \multirow{2}{*}{ Total } & \multirow{2}{*}{$\mathbf{X}^{2}$} & \multirow{2}{*}{ P-value } \\
\hline & Yes & No & & & \\
\hline \multirow{2}{*}{ Single } & 76 & 42 & 118 & \multirow{10}{*}{27.315} & \multirow{10}{*}{$\mathbf{P}<\mathbf{0 . 0 0 1}$} \\
\hline & $64.4 \%$ & $35.6 \%$ & $100.0 \%$ & & \\
\hline \multirow{2}{*}{ Married } & 122 & 12 & 134 & & \\
\hline & $91.0 \%$ & $9.0 \%$ & $100.0 \%$ & & \\
\hline \multirow{2}{*}{ Divorced } & 2 & 0 & 2 & & \\
\hline & $100.0 \%$ & $0.0 \%$ & $100.0 \%$ & & \\
\hline \multirow{2}{*}{ Widowed } & 5 & 1 & 6 & & \\
\hline & $83.3 \%$ & $16.7 \%$ & $100.0 \%$ & & \\
\hline \multirow{2}{*}{ Total } & 205 & 55 & 260 & & \\
\hline & $78.8 \%$ & $21.2 \%$ & $100.0 \%$ & & \\
\hline
\end{tabular}

At a Chi-square value of 27.315 , the p-value is less than $<0.001$, hence there is a statistically significant difference 
between knowledge of temporary artificial contraceptives and marital status.

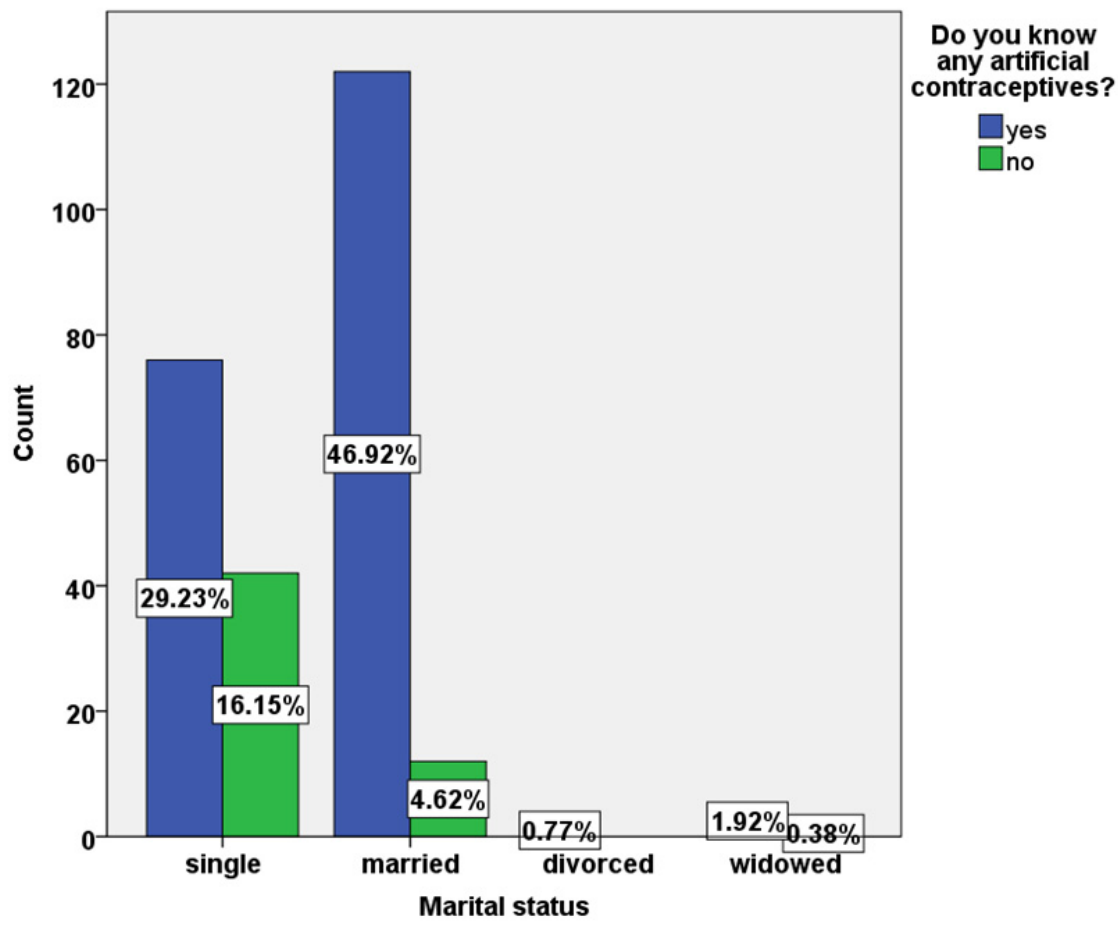

Figure 1. Clustered bar chart comparing the knowledge of temporary artificial contraceptives to marital status

Among the single, $29.23 \%$ had knowledge of temporary artificial contraceptives while $46.92 \%$ of the married women were aware of temporary artificial contraceptives. The highest knowledge of temporary artificial contraceptives was seen among the married, followed by the single.

Table 4. Cross tabulation comparing the knowledge of temporary artificial contraceptives with the highest level of education

\begin{tabular}{|c|c|c|c|c|c|}
\hline & \multicolumn{2}{|c|}{ Do you know any temporary artificial contraceptives? } & \multirow{2}{*}{ Total } & \multirow{2}{*}{$\mathbf{X}^{2}$} & \multirow{2}{*}{ P-value } \\
\hline & Yes & No & & & \\
\hline \multirow{2}{*}{ No formal education } & 7 & 0 & 7 & \multirow{10}{*}{23.928} & \multirow{10}{*}{$<0.001$} \\
\hline & $100.0 \%$ & $0.0 \%$ & $100.0 \%$ & & \\
\hline \multirow{2}{*}{ Primary school completed } & 15 & 8 & 23 & & \\
\hline & $65.2 \%$ & $34.8 \%$ & $100.0 \%$ & & \\
\hline \multirow{2}{*}{ Secondary school completed } & 60 & 32 & 92 & & \\
\hline & $65.2 \%$ & $34.8 \%$ & $100.0 \%$ & & \\
\hline \multirow{2}{*}{ Tertiary education } & 115 & 13 & 128 & & \\
\hline & $89.8 \%$ & $10.2 \%$ & $100.0 \%$ & & \\
\hline \multirow{2}{*}{ Total } & 197 & 53 & 250 & & \\
\hline & $78.8 \%$ & $21.2 \%$ & $100.0 \%$ & & \\
\hline
\end{tabular}

At a Chi-square value of 23.928 , the p-value is less than $<0.001$, hence there is a statistically significant difference between knowledge of temporary artificial contraceptives and the highest level of education. 


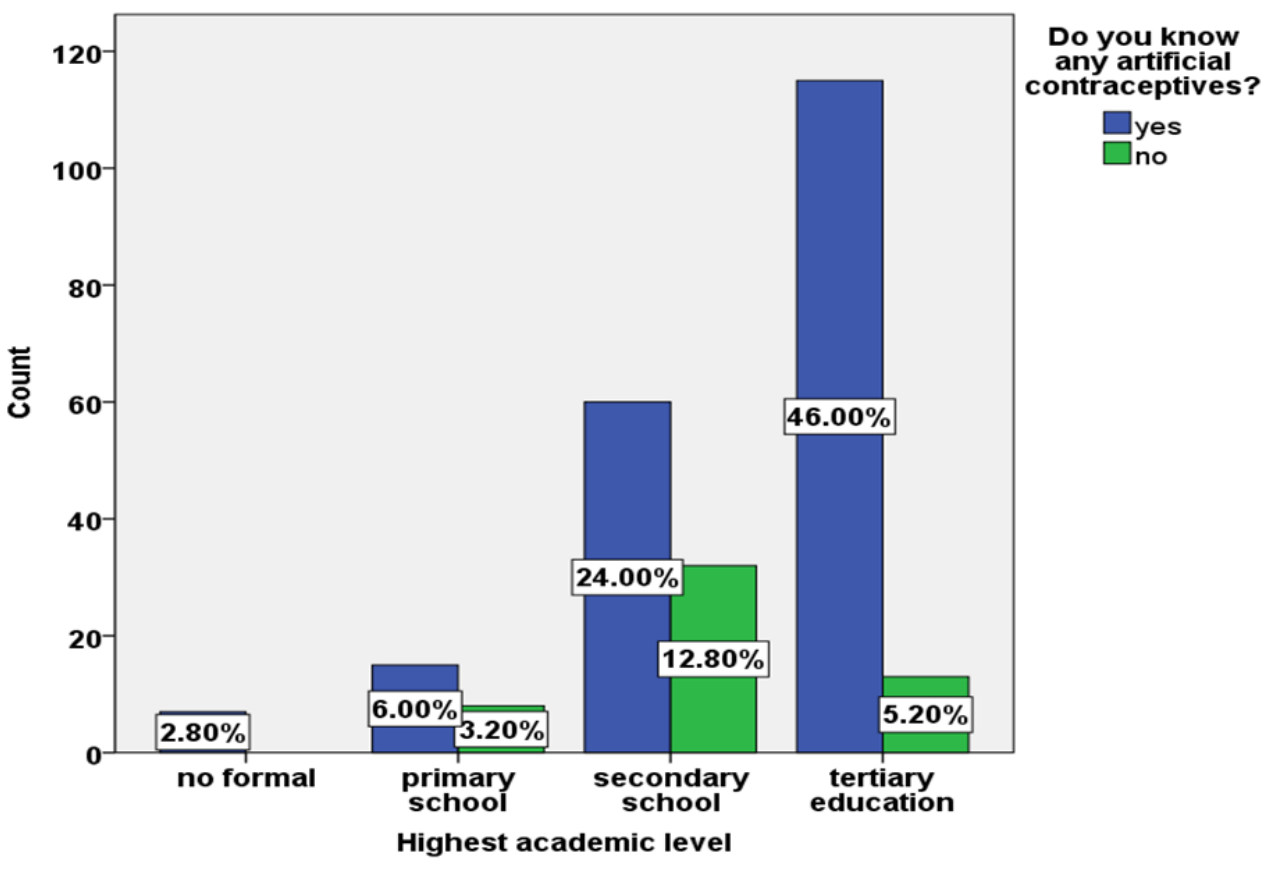

Figure 2. Clustered bar chart comparing the knowledge of temporary artificial contraceptives to the highest level of education

Those with tertiary education had the highest knowledge of temporary artificial contraceptives (46\%), followed by those with secondary school (24\%) and the least was seen with those with no formal education $(2.80 \%)$.

Table 5. Attitude towards temporary artificial contraception

\begin{tabular}{|c|c|c|c|c|c|}
\hline Questions on Attitude & $\begin{array}{l}\text { Strongly } \\
\text { Disagree }\end{array}$ & Disagree & $\begin{array}{l}\text { Not } \\
\text { Sure }\end{array}$ & Agree & $\begin{array}{l}\text { Strongly } \\
\text { Agree }\end{array}$ \\
\hline \multirow{2}{*}{$\begin{array}{l}\text { Do you agree that temporary temporary artificial contraceptives } \\
\text { are a healthy practice? }\end{array}$} & 17 & 60 & 32 & 126 & 25 \\
\hline & $6.5 \%$ & $23.1 \%$ & $12.3 \%$ & $48.5 \%$ & $9.6 \%$ \\
\hline \multirow{2}{*}{$\begin{array}{l}12 \text { Do you think oral pills are better than condoms and } \\
\text { intrauterine device? }\end{array}$} & 12 & 109 & 109 & 27 & 0 \\
\hline & $4.7 \%$ & $42.4 \%$ & $42.4 \%$ & $10.5 \%$ & $0.0 \%$ \\
\hline \multirow{2}{*}{$\begin{array}{l}13 \text { Do you think condoms are better than pills and intrauterine } \\
\text { devices? }\end{array}$} & 12 & 80 & 104 & 60 & 5 \\
\hline & $4.6 \%$ & $30.7 \%$ & $39.8 \%$ & $23.0 \%$ & $1.9 \%$ \\
\hline \multirow{2}{*}{$\begin{array}{l}{ }^{14} \text { Do you think the intrauterine device is better than condoms } \\
\text { and pills? }\end{array}$} & 16 & 112 & 110 & 17 & 5 \\
\hline & $6.2 \%$ & $43.1 \%$ & $42.3 \%$ & $6.5 \%$ & $1.9 \%$ \\
\hline \multirow{2}{*}{$\begin{array}{l}\text { Do you believe that these methods of temporary temporary } \\
\text { artificial contraceptives listed in } 12,13 \text { and } 14 \text { above really work } \\
\text { in preventing pregnancy? }\end{array}$} & 2 & 19 & 48 & 147 & 45 \\
\hline & $0.8 \%$ & $7.3 \%$ & $18.4 \%$ & $56.3 \%$ & $17.2 \%$ \\
\hline \multirow{2}{*}{$\begin{array}{l}\text { Do you believe that using temporary temporary artificial } \\
\text { contraceptives will help reduce material deaths? }\end{array}$} & 20 & 62 & 69 & 91 & 18 \\
\hline & $7.7 \%$ & $23.8 \%$ & $26.5 \%$ & $35.0 \%$ & $6.9 \%$ \\
\hline \multirow{2}{*}{ Do you believe they will help in population control? } & 5 & 23 & 61 & 119 & 49 \\
\hline & $1.9 \%$ & $8.9 \%$ & $23.7 \%$ & $46.3 \%$ & $19.1 \%$ \\
\hline \multirow{2}{*}{$\begin{array}{l}\text { Do you believe that oral contraceptive pills and intrauterine } \\
\text { devices also protect against sexually transmitted infections? }\end{array}$} & 67 & 75 & 80 & 35 & 4 \\
\hline & $25.7 \%$ & $28.7 \%$ & $30.7 \%$ & $13.4 \%$ & $1.5 \%$ \\
\hline
\end{tabular}

Note. Strongly agree $=1$, Agree $=2$, Not sure $=3$, Disagree $=4$, Strongly disagree $=5$. 
From the table, $48.5 \%$ agreed that the use of temporary artificial contraceptives is a healthy practice, $42.4 \%$ think that oral pills are better than condoms and intrauterine devices. 35\% agreed that using temporary artificial contraceptives can help reduce maternal mortality. Other responses to questions on knowledge are well summarized in the table

Table 6. Cross tabulation between attitude towards temporary artificial contraceptives and marital status

\begin{tabular}{|c|c|c|c|c|c|c|c|c|}
\hline \multirow{2}{*}{$\begin{array}{l}\text { Marital } \\
\text { Status }\end{array}$} & \multicolumn{5}{|c|}{$\begin{array}{l}\text { Do you agree that temporary artificial contraceptives are a healthy } \\
\text { practice? }\end{array}$} & \multirow[t]{2}{*}{ Total } & \multirow[t]{2}{*}{$\mathbf{X}^{2}$} & \multirow[t]{2}{*}{ P-value } \\
\hline & Strongly Disagree & Disagree & Not Sure & Agree & Strongly Agree & & & \\
\hline \multirow[t]{2}{*}{ Single } & 10 & 38 & 17 & 47 & 6 & 118 & \multirow{10}{*}{23.029} & \multirow{10}{*}{0.027} \\
\hline & $8.5 \%$ & $32.2 \%$ & $14.4 \%$ & $39.8 \%$ & $5.1 \%$ & $100.0 \%$ & & \\
\hline \multirow[t]{2}{*}{ Married } & 6 & 22 & 14 & 74 & 17 & 133 & & \\
\hline & $4.5 \%$ & $16.5 \%$ & $10.5 \%$ & $55.6 \%$ & $12.8 \%$ & $100.0 \%$ & & \\
\hline \multirow[t]{2}{*}{ Divorced } & 0 & 0 & 0 & 1 & 1 & 2 & & \\
\hline & $0.0 \%$ & $0.0 \%$ & $0.0 \%$ & $50.0 \%$ & $50.0 \%$ & $100.0 \%$ & & \\
\hline \multirow[t]{2}{*}{ Widowed } & 1 & 0 & 1 & 3 & 1 & 6 & & \\
\hline & $16.7 \%$ & $0.0 \%$ & $16.7 \%$ & $50.0 \%$ & $16.7 \%$ & $100.0 \%$ & & \\
\hline \multirow[t]{2}{*}{ Total } & 17 & 60 & 32 & 125 & 25 & 259 & & \\
\hline & $6.6 \%$ & $23.2 \%$ & $12.4 \%$ & $48.3 \%$ & $9.7 \%$ & $100.0 \%$ & & \\
\hline
\end{tabular}

At a Chi-square value of 23.029 , the p-value is 0.027 , hence there is a statistically significant difference between marital status and attitude towards the use of temporary artificial contraceptives.

Table 7. Use of Temporary artificial contraceptives

\begin{tabular}{lll}
\hline Use of Temporary artificial contraceptives & Yes & No \\
\hline Have you used temporary artificial contraceptives before? & 127 & 131 \\
\hline Have you used condoms for contraception? & $49.2 \%$ & $50.8 \%$ \\
\hline Have you used oral contraceptive pills? & 135 & 119 \\
& $53.1 \%$ & $46.9 \%$ \\
\hline Have you used Intra-uterine contraceptive devices? & 17 & 237 \\
\hline Used other: implants & $6.7 \%$ & $93.3 \%$ \\
\hline
\end{tabular}

From the table, $49.2 \%$ had used temporary artificial contraceptives before, $53.1 \%$ had used a condom, $6.7 \%$ had used oral contraceptives while $1.6 \%$ had used intrauterine contraceptive devices 
Table 8. Cross tabulation comparing the use of temporary artificial contraceptives and marital status

\begin{tabular}{|c|c|c|c|c|c|}
\hline \multirow[t]{2}{*}{ Marital Status } & \multicolumn{2}{|c|}{$\begin{array}{l}\text { Have you used temporary artificial } \\
\text { contraceptives before? }\end{array}$} & \multirow[t]{2}{*}{ Total } & \multirow[t]{2}{*}{$X^{2}$} & \multirow[t]{2}{*}{ P-value } \\
\hline & Yes & No & & & \\
\hline \multirow[t]{2}{*}{ Single } & 30 & 86 & 116 & \multirow{10}{*}{48.282} & \multirow{10}{*}{$<0.001$} \\
\hline & $25.9 \%$ & $74.1 \%$ & $100.0 \%$ & & \\
\hline \multirow[t]{2}{*}{ Married } & 90 & 43 & 133 & & \\
\hline & $67.7 \%$ & $32.3 \%$ & $100.0 \%$ & & \\
\hline \multirow[t]{2}{*}{ Divorced } & 2 & 0 & 2 & & \\
\hline & $100.0 \%$ & $0.0 \%$ & $100.0 \%$ & & \\
\hline \multirow[t]{2}{*}{ Widowed } & 5 & 1 & 6 & & \\
\hline & $83.3 \%$ & $16.7 \%$ & $100.0 \%$ & & \\
\hline \multirow[t]{2}{*}{ Total } & 127 & 130 & 257 & & \\
\hline & $49.4 \%$ & $50.6 \%$ & $100.0 \%$ & & \\
\hline
\end{tabular}

At a Chi-square value of 48.282 , the p-value is less than $<0.001$, hence there is a statistically significant difference between the use of temporary artificial contraceptive and marital status.

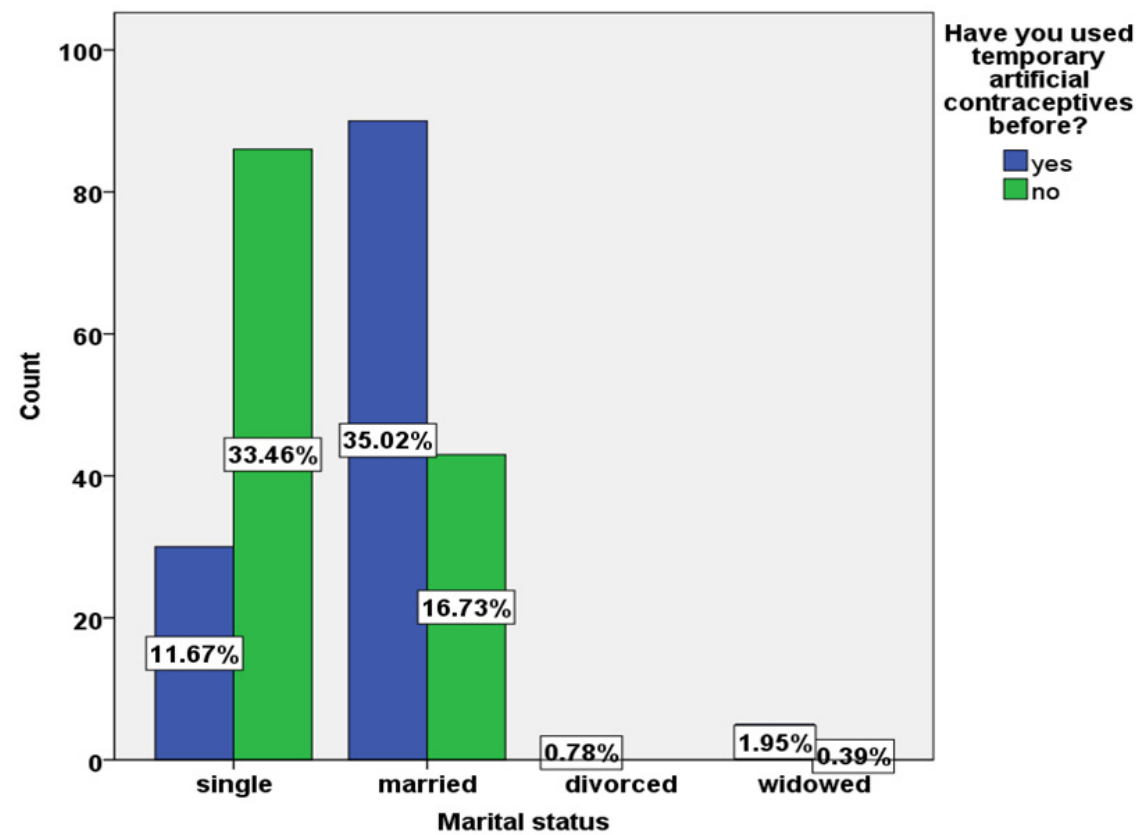

Figure 3. Clustered bar chart comparing the use of temporary artificial contraceptives to marital status

Use of temporary artificial contraceptives was highest among the married $(35.02 \%)$, followed by the single $(11.67 \%)$ and the least was seen among the divorced $(0.78 \%)$. 
Table 9. Cross tabulation between the use of temporary artificial contraceptives and level of education

\begin{tabular}{|c|c|c|c|c|c|}
\hline & \multicolumn{2}{|c|}{$\begin{array}{l}\text { Have you used temporary artificial } \\
\text { contraceptives before? }\end{array}$} & \multirow[t]{2}{*}{ Total } & \multirow[t]{2}{*}{$\mathbf{X}^{2}$} & \multirow[t]{2}{*}{ P-value } \\
\hline & yes & no & & & \\
\hline \multirow{2}{*}{ No formal education } & 3 & 3 & 6 & \multirow{10}{*}{15.401} & \multirow{10}{*}{0.220} \\
\hline & $50.0 \%$ & $50.0 \%$ & $100.0 \%$ & & \\
\hline \multirow{2}{*}{ Primary school completed } & 10 & 13 & 23 & & \\
\hline & $43.5 \%$ & $56.5 \%$ & $100.0 \%$ & & \\
\hline \multirow{2}{*}{ Secondary school completed } & 39 & 53 & 92 & & \\
\hline & $42.4 \%$ & $57.6 \%$ & $100.0 \%$ & & \\
\hline \multirow{2}{*}{ Tertiary education } & 68 & 58 & 126 & & \\
\hline & $54.0 \%$ & $46.0 \%$ & $100.0 \%$ & & \\
\hline \multirow{2}{*}{ Total } & 120 & 127 & 247 & & \\
\hline & $48.6 \%$ & $51.4 \%$ & $100.0 \%$ & & \\
\hline
\end{tabular}

At a Chi-square value of 15.401 , the p-value is 0.220 , hence there is no statistically significant difference between the use of temporary artificial contraceptives and the participants level of education.

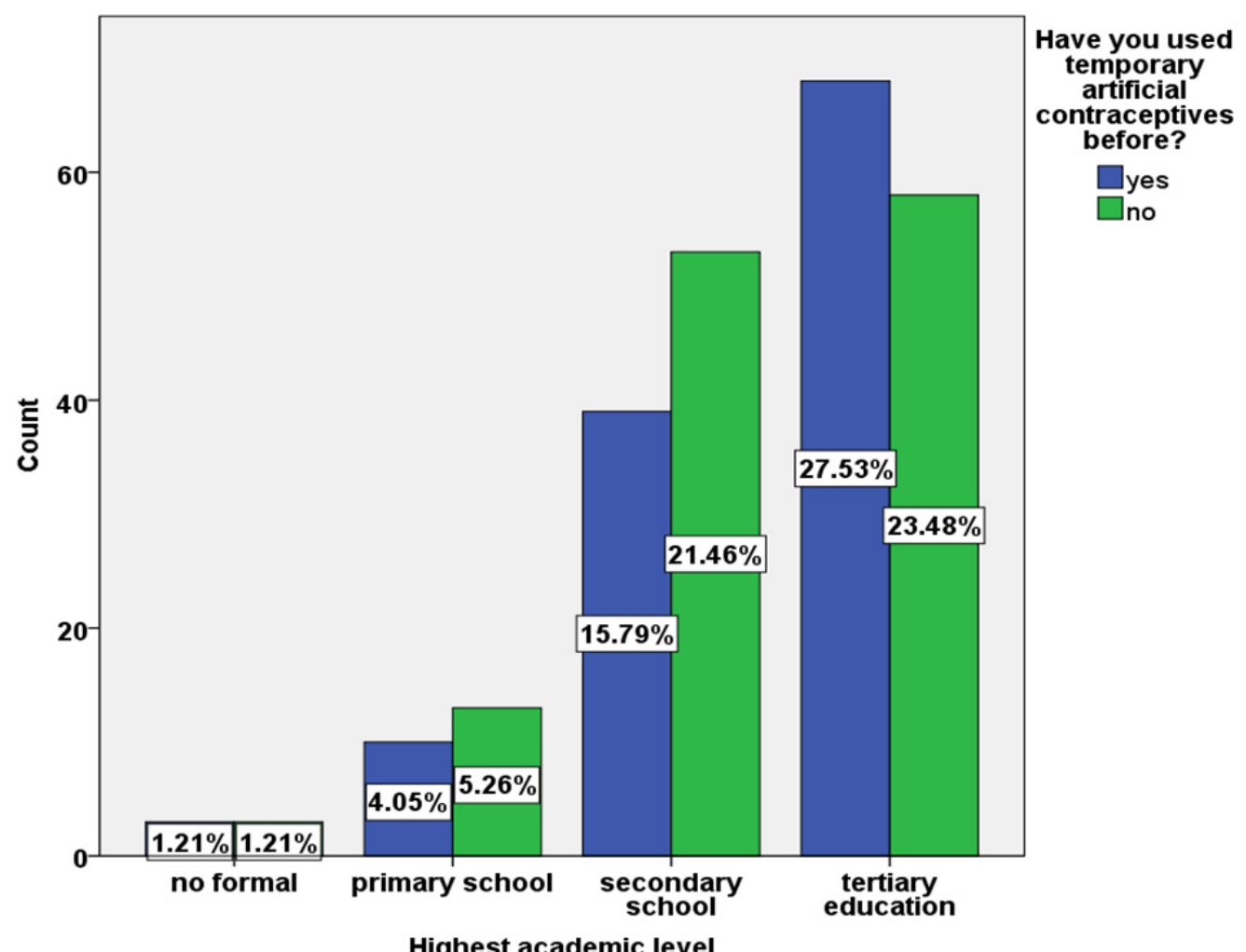

Figure 4. Clustered bar chart comparing the use of temporary artificial contraceptives to the highest level of education

Those with tertiary education had the highest use of temporary artificial contraceptives (27.53\%), followed by those with secondary school (15.79\%) and the least was seen with those with no formal education $(1.21 \%)$. 
Table 10. Cross tabulation comparing the use of temporary artificial contraceptive and Religion

\begin{tabular}{|c|c|c|c|c|c|}
\hline \multirow{2}{*}{ Religion or Denomination } & \multicolumn{2}{|c|}{ Have you used temporary artificial contraceptives before? } & \multirow{2}{*}{ Total } & \multirow{2}{*}{$\mathbf{X}^{2}$} & \multirow{2}{*}{ P-value } \\
\hline & Yes & No & & & \\
\hline \multirow[t]{2}{*}{ Catholics } & 64 & 72 & 136 & & \\
\hline & $47.1 \%$ & $52.9 \%$ & $100.0 \%$ & & \\
\hline \multirow[t]{2}{*}{ Anglican } & 8 & 12 & 20 & & \\
\hline & $40.0 \%$ & $60.0 \%$ & $100.0 \%$ & & \\
\hline \multirow[t]{2}{*}{ Pentecostal } & 55 & 43 & 98 & 6.680 & 0.083 \\
\hline & $56.1 \%$ & $43.9 \%$ & $100.0 \%$ & & \\
\hline \multirow[t]{2}{*}{ Muslim } & 0 & 4 & 4 & & \\
\hline & $0.0 \%$ & $100.0 \%$ & $100.0 \%$ & & \\
\hline \multirow[t]{2}{*}{ Total } & 127 & 131 & 258 & & \\
\hline & $49.2 \%$ & $50.8 \%$ & $100.0 \%$ & & \\
\hline
\end{tabular}

At a Chi-square value of 6.680 , the p-value is 0.083 , hence there is no statistically significant difference between the use of temporary artificial contraceptives and religion.

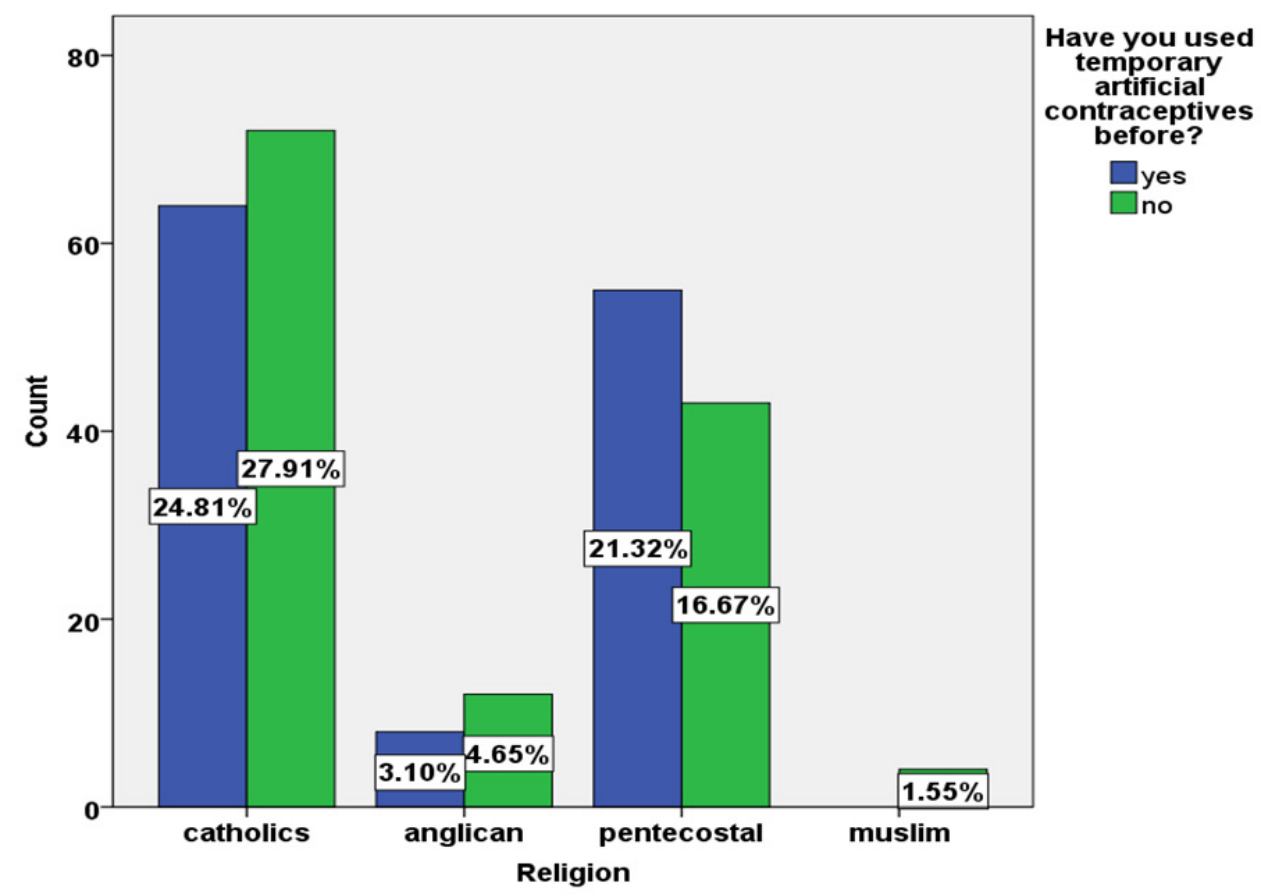

Figure 5. Clustered bar chart comparing the use of temporary artificial contraceptives with respect to Religion

Use of temporary artificial contraceptives was highest among Christians of the Roman Catholic denomination (24.81\%), followed Christians of the Pentecostal denomination (21.32\%), followed by the Anglicans (3.10\%) and the least was seen among the Muslims (1.55\%).

\section{Discussion}

4.1 Discussion on Knowledge of Temporary Artificial Contraceptives in Women of Child Bearing Age in Awka South Local Government Area

From this study 206 out of the 261 respondents knew about temporary artificial contraceptives, that is, most of the respondents had knowledge of temporary artificial contraceptives. This is in contrast to a similar study done in 
North India, where only $55.2 \%$ of the respondents were aware of temporary artificial methods of contraception (Inflibnex, 2018) this could be due to the low level of sensitization or lack of sincerity on the part of the respondents. Our work, however, is in line with a similar study done in Argentina on female students, which showed 71.5\% knowledge of temporary artificial contraceptives $(n=672, p>0.002)$ (Nakim et al., 2013)

It is also in line with a similar study done in Addis Ababa, Ethiopia, where $86 \%$ of the respondents (134/156) had knowledge of temporary artificial contraceptives (Inflibnex, 2018).

In Nigeria, similar studies conducted in Enugu state showed a knowledge level of temporary artificial contraceptives to be $97.6 \%(n=334)$ (Inflibnex, 2018).

In this study, most of the respondents with knowledge of temporary artificial contraceptives got their information from friends [ 89 out of 201(44.3\%)] followed by the school [45 out of 201(22.4\%)]. This reflects a low level of sex education in our homes and religious institutions.

Of the 206 that had knowledge of temporary artificial contraceptives, condoms were the most known, followed by oral pills and then intra uterine devices. Only $18.4 \%$ could actually identify intra-uterine contraceptive devices from a list of options While $43.2 \%$ could actually identify a contraceptive pill within a list of options. These are in line with a similar study done Kinshasa, Congo Republic (Knust-edu, 2003).

There was a statistically significant difference between the level of knowledge of temporary artificial contraceptives and marital status, there was a strong relationship between being married and having knowledge of temporary artificial contraceptives (chi-squared $=27.315, \mathrm{P}<0.001$ ) hence the null hypothesis which states that there is no difference between the knowledge of temporary artificial contraceptives and marital status in women of childbearing age in Awka South local government areas rejected and the alternate hypothesis accepted.

From the study, there was a statistically significant difference between knowledge of temporary artificial contraceptives and educational attainment $\left(\mathrm{chi}^{2}=23.928, \mathrm{P}<0.000\right)$.

This study also showed that the oral contraceptive pill most known to these women is postinor-2 (61/121, 50.4\%) while the intra-uterine device most commonly known to those with knowledge of intra-uterine contraceptive device was Mirena, $(65.8 \%, \mathrm{n}=38)$

4.2 Discussion on Attitude Towards Temporary Artificial Contraceptives Among Women of Child Being Age in Awka-South Local Government Area

A total of 151 respondents out of the $260(58.1 \%)$ had a positive attitude towards the use of while $12.3 \%$ were indifferent temporary artificial contraceptives. this is in contrast to a similar study done in Ethiopia, where $71.5 \%$ of the respondents had favourable attitude towards the use of temporary artificial contraceptives $(n=263)$ (Benta et al., 2017). This difference could be due to wrong cultural beliefs in this part of the country, or lack of proper orientation on the benefits of using temporary artificial contraceptives.

The result of this study also corresponds closely to that obtained from survey on attitude towards temporary artificial contraceptives, in Akwa-Ibom, State Nigeria, Where 67.2\% of the respondents had a positive attitude towards temporary artificial contraceptives $(n=338)$ (Ekong, 2016), however there was Sharp contrast in attitude when a study of like nature was carried out in a South Eastern state of Nigeria, Enugu State where Up to $86.2 \%$ of the respondents were of favorable attitude. The reason for this disparity is not clear, but environmental factors may play a Role since the study was done in an urban area (Inflibnex, 2018). In this study, comparison between the attitudes towards temporary artificial contraceptives in married a unmarried persons showed a statistically significant difference (chi-squared $=23.029, \mathrm{P}=0.027$ ) most of the married persons had a positive attitude, again, we reject the null which stated that there is no difference in the attitude towards temporary artificial contraceptives with respect to marital status, thereby accepting the alternate hypothesis.

The source of knowledge also had a positive impact on attitude, with those that obtained information from hospitals and schools showing more favorable attitude, unlike those who got from friends.

Surprisingly, many people who had a positive attitude towards temporary artificial contraceptives did not agree that it will help reduce the number of maternal deaths and most of those that lacked formal education felt that the pills could also prevent sexually transmitted diseases.

\subsection{Discussion on Practice of Temporary Artificial Contraceptives}

Information gathered in this survey revealed that out of 258 respondents, only 127 admitted to having used temporary artificial contraceptives. (49.2\%). This is in accordance with the results of a similar study in North India, where $45.3 \%$ of the respondent admitted to having used one or more methods of temporary artificial contraceptives 
(Inflibnex, 2018), while a further decline in use was recorded in a survey on use of temporary artificial contraceptives among female students in Ethiopia, where a total of 39 persons out of 263 participants (Response rate $=91.3 \%$ ) had ever used artificial contraceptives. This is just $15.7 \%$ of the respondents.

In Enugu State, Nigeria, only $20 \%$ of the participants have ever used a contraceptive method according to a research done there (Inflibnex, 2018), this contrasts with the results obtained from this our study.

A similar study in Delta State showed results which was consistent with that of our study, in that research, $42.9 \%$ of the participation had used temporary artificial contraceptives at some time (Inflibnex, 2018).

With respect to marital status, our survey showed a statistically significant difference in the level of usage of temporary artificial contraceptives $\left(x^{2}=48.282, \mathrm{P}>0.001\right)$, again, we reject our null which stated that there is no difference in the level of practice of temporary artificial contraceptives between married and unmarried women in Awka South local government area. There was definitely a strong relation between being married and using temporary artificial contraceptives, however, this contrasts with the observation from similar study in Ethiopia, where the usage was higher in single respondents (66.7\%).

A possible explanation for this may be the stigmata and adverse cultural beliefs attached to premarital sex in our study Area, which may make the single respondents give false answers to their usage of temporary artificial contraceptives.

The investigation of the relationship between educational level and usage of temporary artificial contraceptives yielded a negative result, likewise that for religion and use.

\section{Conclusion}

Despite a high level of awareness of temporary artificial contraceptives methods, its level of practice is quite low in this part of the country.

The major factors influencing the knowledge and attitude of the participants towards temporary artificial contraceptives are marital status and educational level while the major factor affecting the use is marital status.

\subsection{Recommendations}

1) The government should subsidize materials and services for temporary artificial contraception, as this will encourage its practice.

2) Special seminars/workshops should be organized periodically on the proper use of temporary artificial contraceptives and such should also be included in the routine activities of government health facilities.

This survey demonstrated a low level of sensitization about temporary artificial contraceptives in family homes and religious institutions. The persons in charge of these places should discuss sexuality and it is safe practices more frequently with the members.

\section{Competing Interests Statement}

The authors declare that there are no competing or potential conflicts of interest.

\section{References}

Akin, A. (2006). Textbook of Obstetrics and Gynecology for medical students. Heinemann educational books (2nd ed., pp. 145-154). Nigeria.

American Experience. (2016). The Pill. Retrieved May 23, 2018, from https://m.imdb.com>title.

Amy, N., \& Cuomo, C. (2010). Birth control in O'Reilly. Encyclopedias of motherhood (121-126). Thousand Oaks. Calif Sage publications.

Beker, C., Clifford, K., \& Lipsey. (2005). Richard Historical record on the control of family size. Economic transformation. London. Oxford University Press.

Benta, T., Elias, T., Ifa, M. (2017). Knowledge, attitude and practice of emergency contraception among female students. Journal of medicine, Physiology and Biophysics, (36). Retrieved May 26, 2018, from https://liste.org $>$ articles $>$ knowledge_attitude_and_practice_of_emergency_contraception_among_female_st udents

Blogger. (2013). Awka as a city. Retrieved May 24, 2018, from awkacity.blogspot.co.ke

Dingwall, E. J. (1953). Early contraceptive sheaths. Britain. British Med publishers. Retrieved May 22, 2018, from https://ncbi.nlm.nih.gov/pmc/articles/pmc2015111 
Draznin, Y. C. (2001). What she did all day (pp. 98-100). West port, Connecticut. Greenwood press.

Ekong, J. (2016). Knowledge, Attitude and Practice of Family Planning among Women in a Rural Community in Southern Nigeria. British journal of Medicine and Medical researches, 12(2), 1-8. https://doi.org/10.9734/BJMMR/2016/21840

Emechebe, C. I., Njoku, C. O., Udofia, U. M., \& Ukaga, J. T. (2016) Complications of induced abortions. contributions to maternal mortality in a tertiary center of a low resource setting. Saudi J health Sci, 34-8. https://doi.org/10.4103/2278-0521.182864

Ezebialu, I. U., \& Eke, A. C. (2013). Knowledge and Practice of Emergency ContraceptionAmong Female Undergraduates in South Eastern Nigeria. Annals of Medical and Health Sciences Research, 3(4), 541-545. https://doi.org/10.4103/2141-9248.122092

Fritz, M., \& Speroff, L. (2011). Intra uterine contraception. Philadelphia. Lippincot Williams and Wilkins, 1095-1098.

Fryer, P. (2018). The birth controllers. London. Secker and Warburg. 1965. Retrieved from https://scissors-and-paste.net>peter_fryer

Hall, R. (1977). Passionate Crusader (p. 186). Harcout. Jovanovich press,

Ikechebelu, J. (2009). Knowledge, attitude and practice of family planning among Igbo women of south eastern Nigeria (pp. 790-795). Retrieved May 24, 2018, from https://www.reaserchgate.net>publication7401537

Inflibnex. (2018). Literature review. Retrieved May 25, 2018, from Shodhganga-inflibnex.ac.in $>$ bitstream $>$ literature review

Knust-edu. (2003). Research results. Retrieved May 24, 2018, from Ir.knust.edu.gh $>$ bitstream $>1$ research result.

Medicine Net. (2018). Definition of birth control. Educational Journals. Retrieved May 21, 2018, from https://www.medicinenet.com/script/main/art.asp?articlekey=53351

Nakkim, M., Nicolas, F., \& Stedding, F. (2013). Knowledge and attitude towards family planning among first year students at the Faculty of Medicine at the University of Buenos Aires, Argentina. Master thesis Journal, 20(8), $12-20$.

National bureau of statistics. (2006). Figures from National population commission of Nigeria. Retrieved May 24, 2018, from www.citypopulation.de

Populations reference Bureau. (2018). Unsafe abortions. Retrieved May 23, 2018, from www.prb.org>pdf06

RAND. (1997). The value of family planning programs in developing countries. Cartley catson international. Retrieved May 26, 2018, from https://www.ncbi.nlm.nih.gov/m/pubmed/9253672

Times. (2016). Herbal arbortifacients in Bullough. Encyclopedia of birth control. Santa Barbara, 125-128. Retrieved May 22, 2018 from https://books.google.com.ng>books

USAID. (2012). United nations population fund. Retrieved May 23, 2018, from https://blog.usaid.gov

Wikipedia (2018). World contraception day. Retrieved May 23, 2018, from http://en.m.wikipedia.org/wiki/world_contraception_day

Wikipedia. (2018). Obi continues to make impact in Awka. Local Government Areas in Anambra state. Retrieved May 24, 2018, from https://en.m.wikipedia.org/wiki/awka_south

World Health Organization [WHO]. (2018). International safe abortion day. Retrieved May 23, 2018, from Https://www.ippf.org>sites $>$ defaultfiles

World Population Reviews. (2018). Nigeria population 2018. Retrieved October 31, 2018, from worldpopulationreview.com/countries/nigerianpopulation

\section{Copyrights}

Copyright for this article is retained by the author(s), with first publication rights granted to the journal.

This is an open-access article distributed under the terms and conditions of the Creative Commons Attribution license (http://creativecommons.org/licenses/by/4.0/). 